\title{
HLA class II and T-cell receptor $\beta$ chain polymorphisms in Belgian patients with rheumatoid arthritis: no evidence for disease association with the TCRBC2, TCRBV8 and TCRBV11 polymorphisms
}

Caroline Vandevyver, Xiao Xiao Gu, Piet Geusens, Marijke Spaepen, Linda Philippaerts, Jean-Jacques Cassiman and Jef Raus

\begin{abstract}
Objectives-To investigate whether T-cell receptor (TCR) $\beta$ chain germline alleles, either alone or in combination with a particular HLA-genotype, are associated with rheumatoid arthritis (RA).

Methods-Three restriction fragment length polymorphisms (RFLPs), detected with TCR constant (TCRBC2) and variable (TCRBV8, TCRBV11) gene segments were analysed in a representative group of Belgian, HLA class IItyped patients with $R A$, and in a group of Belgian control subjects.

Results-The study confirmed the known association of RA with the HLADRB1 $\star 0401 / 0404$ genotype $(R R=2 \cdot 14,95 \%$ $\mathrm{CI}=1 \cdot 16-4 \cdot 00)$ in the Belgian RA population. This association was even more pronounced in the patients with more severe $R A(R R=3 \cdot 26,95 \%$ CI $=1 \cdot 55-$ $6 \cdot 89)$. These data suggest that the HLADRB1`04 genotype can be used as a marker for disease severity. Similar frequencies in patients and controls were observed for all TCRB RFLPs studied, and this was in spite of subgrouping the RA population according to criteria for disease stratification.
\end{abstract}

Immunologyl

Biotechnology,

Dr L Willems-Instituut, and the Limburgs Universitair Centrum, Diepenbeek, Belgium

C Vandevyver

L Philippaerts

J Raus

Department of

Rheumatology,

Katholieke Universiteit

Leuven, Belgium

$P$ Geusens

Center for Human

Genetics, Katholieke Universiteit Leuven, Belgium

$\mathrm{XXGu}$

M Spaepen

J-J Cassiman

Correspondence to:

Dr Caroline Vandevyver, $\mathrm{Dr}$

L Willems-Instituut,

Department of

Immunology/Biotechnology,

Universitaire Campus Bldg

A, B-3590 Diepenbeek, Belgium.

Accepted for publication 13 May 1994 synovial membranes of articulating joints. RA develops in genetic susceptible hosts, and is responsible for severe disability and increased mortality. ${ }^{1}$ The aetiology of the disease is still unknown, but there is some evidence that a cell-mediated process involving $\mathrm{T}$ cells, antigen-presenting cells, macrophages, synoviocytes, and cytokines, play an important role in the immunopathogenesis. ${ }^{2}$

Familial cases of RA do occur, ${ }^{34}$ and this, along with an increased rate of concordance in monozygotic, compared with dizygotic, twins, ${ }^{56}$ suggests that the susceptibility to the disease is inherited, at least in part. It is probable that the susceptibility for $R A$ is determined by a series of genes. The specific loci, however, still needs to be identified.

Part of the genetic susceptibility to RA is accounted for by alleles within the major histocompatibility complex (MHC). This was originally shown by Stastny ${ }^{7}$ as a well established strong association between the antigen HLA-DR4, its subtype Dw4, and RA. Disease associations with HLA-DR 1,89 specific DR-DQ haplotypes, ${ }^{10} 11$ and HLADR6, ${ }^{12}{ }^{13}$ have also been reported. However, the extent of the genetic risk to RA accounted for by these HLA region alleles remains uncertain. This leads to the assumption that the true susceptibility genes for RA still have to be identified. It is most likely that other loci, in addition to environmental influences, are also involved. In this respect, RA is similar to most of the HLA class II-associated autoimmune diseases. Recent studies indicate that the presence of DR4 is associated with the risk for more severe disease. ${ }^{14} 15$

Since the antigen-specific $T$-cell receptor (TCR) plays a central role in immune recognition, variations in the genes encoding for this receptor, could potentially contribute to the development and inheritance of RA. Several reports have described associations of some autoimmune diseases with restriction fragment length polymorphisms (RFLPs) within the TCRA- and TCRB-chain genes. It has been reported that RA may be associated with genetic polymorphisms of the TCRB locus. Gao et al found an association between a particular allelic combination of TCRBV8 ${ }^{2}$ and DR4-positive RA patients. ${ }^{16} 17$ These results have been confirmed by the group of Funkhouser et al. ${ }^{18}$ Other investigators, however, have been unable to confirm this observation. ${ }^{1920}$ 
The aim of the present study was to investigate whether the associations with TCRB chain germline alleles previously reported in RA, could be confirmed in a HLA class II-typed, well defined group of Belgian patients with definite RA. We have studied the germline repertoire of the TCRB chain genes in 88 patients with clinically defined RA and we compared this repertoire to that of 67 unselected, unrelated healthy Belgians.

\section{Patients and methods \\ PATIENT POPULATION}

DNA samples from a group of 88 patients, from different parts of Belgium with clinically definite $\mathrm{RA}^{21}$ were studied (table 1 , total group). Patients selected for this study fulfilled the diagnostic criteria of the American Rheumatism Association (ARA). ${ }^{21}$ Radiographs of the hands and feet were taken each year as were radiographs of other joints if clinically indicated. They were divided into three groups based on the following criteria: all patients were asked about the presence of deforming RA in close family members (siblings, parents, grandparents, aunts and uncles), and relatives were also examined according to the ARA criteria. Group 1 comprised 28 patients with familial RA. Group 2 comprised 48 patients in whom rheumatoid factor was positive. Rheumatoid factor was measured by RA-latex test and Waaler-Rose test, and considered positive at a titre of $>1 / 16$ and/or $>1 / 32$ respectively. Group 3 comprised 33 patients who had definite erosions in the small joints of the hand and/or forefoot. Sixty seven randomly selected healthy individuals, of European White descent, were used as normal controls. All samples were analysed for the TCRB genes, and for the HLA class II-genotypes.

DNA PROBES AND POLYMORPHISM

The following full-length cDNA probes were used: a $\mathrm{B} g l \mathrm{II}-\mathrm{Bgl}$ II fragment $(400 \mathrm{bp}$ ) of the Jurkat TCRB gene, clone JVR- ${ }_{2}{ }^{22}$ kindly provided by $\mathrm{Dr} T$ Mak, Ontario Cancer Institute, Canada. DNA probes corresponding to the human TCRBV8 (Hind III-Eco RI, 324 $\mathrm{bp})^{23}$ and TCRBV11 (Hind III-Eco RI, 425 $\mathrm{bp})^{23}$ were provided by $\operatorname{Dr} \mathrm{P}$ Charmley, Division of Biology, California Institute of Technology, Pasadena, USA.

Table 1 Clinical characteristics of the Belgian $R A$ population studied

\begin{tabular}{|c|c|c|c|c|}
\hline & \multicolumn{4}{|c|}{ Patients with rheumatoid arthritis } \\
\hline & Total group & $\begin{array}{l}\text { Group } 1 \\
\text { Familial } R A\end{array}$ & $\begin{array}{l}\text { Group } 2 \\
R F \text { positive }\end{array}$ & $\begin{array}{l}\text { Group } 3 \\
\text { Erosive } \\
\text { (duration }>8 \mathrm{yr} \text { ) }\end{array}$ \\
\hline Number of patients & 88 & 28 & 48 & 33 \\
\hline $\begin{array}{l}\text { Age (year) } \\
\text { Median } \\
\text { Range }\end{array}$ & $\begin{array}{l}57 \\
22-81\end{array}$ & $\begin{array}{l}55 \\
22-72\end{array}$ & $\begin{array}{l}55 \\
29-81\end{array}$ & $\begin{array}{l}58 \\
35-79\end{array}$ \\
\hline $\operatorname{Sex}(m / f)$ & $30 / 58$ & $9 / 19$ & $20 / 28$ & $15 / 18$ \\
\hline $\begin{array}{l}\text { Disease duration (year) } \\
\text { Median } \\
\text { Range }\end{array}$ & $\begin{array}{l}7 \\
0-37\end{array}$ & $\begin{array}{l}8 \\
1-21\end{array}$ & $\begin{array}{l}9 \\
1-37\end{array}$ & $\begin{array}{l}14 \\
8-37\end{array}$ \\
\hline $\begin{array}{l}\text { Age at disease onset (year) } \\
\text { Median } \\
\text { Range }\end{array}$ & $\begin{array}{l}47 \\
21-78\end{array}$ & $\begin{array}{l}47 \\
21-63\end{array}$ & $\begin{array}{l}46 \\
21-78\end{array}$ & $\begin{array}{l}44 \\
21-60\end{array}$ \\
\hline
\end{tabular}

Plasmid inserts were prepared by restriction digest, electrophoresis, and isolation of the probe by extracting the appropriate DNA band from the gel with sterile glass wool.

$B g l$ II blots were used to identify the TCRBC2 gene polymorphisms, with bands present at $9 \mathrm{~kb}$ and $10 \mathrm{~kb}$. TCRBV polymorphisms were identified with Bam HI blots. The TCRBV8/Bam HI polymorphism was identified by bands at $23 \mathrm{~kb}$ and $2 \mathrm{~kb}$, while the TCRBV11/Bam HI RFLP showed bands at $25 \mathrm{~kb}$ and $20 \mathrm{~kb}$.

\section{DNA PREPARATION AND HYBRIDISATION}

Genomic DNA was prepared from whole blood and subjected to restriction digests with $B a m \mathrm{HI}$ or $\mathrm{Bgl} \mathrm{II}$, using conditions as specified by the manufactures. ${ }^{24}$

Fifteen $\mu \mathrm{g}$ of the restricted DNA was sizeseparated on $0.8 \%$ agarose gels by electrophoresis for 24-28 hours at 22-24 V, and transferred by vacuum blotting to Zeta-Probe GT (Bio-Rad) nylon membranes, according to the manual of the manufacturers. Pre hybridisation was performed for minimal 15 minutes in $0.25 \mathrm{M}$ sodium phosphate $\mathrm{pH} 7.2$, $7 \%$ SDS, in the presence of $100 \mu \mathrm{g} / \mathrm{ml}$ denatured herring sperm DNA, at $65^{\circ} \mathrm{C}$. Hybridisations were carried out for 15-24 hours at $65^{\circ} \mathrm{C}$ in a pre hybridisation mixture supplemented with $1-2 \mathrm{ng} / \mathrm{ml}$ denatured probe.

The filters were washed (1-2 times) in 20 $\mathrm{mM}$ sodium phosphate, $\mathrm{pH} 7 \cdot 2$ and $5 \%$ SDS at $65^{\circ} \mathrm{C}$ for 30 minutes and $1-2$ times in 20 $\mathrm{mM}$ sodium phosphate, $\mathrm{pH} 7 \cdot 2$ and $1 \%$ SDS at $65^{\circ} \mathrm{C}$ for 30 minutes. The blots were autoradiographed using a hyperfilm MP (Amersham, UK), in cassettes with intensifying screens, for $24-72 \mathrm{~h}$.

\section{HAPLOTYPE ASSIGNMENT}

The haplotypes for the normal subjects and RA patients were determined for all individuals heterozygous at not more than one locus. Without segregation information the haplotype phase cannot be deducted for persons who were double heterozygous for one locus.

PCR AMPLIFICATION AND SSO-HLA TYPING

All patients and controls were typed for the DRB1, DRB3, DRB4, DRB5 alleles as described previously. ${ }^{25}$ Briefly, the four DRB genes were coamplified by the PCR and subsequently hybridised by one single hybridisation assay to DRB sequence specific oligonucleotides (SSO) using a rapid and nonisotopic reverse dot blot. The originally described DRB hybridisation protocols were adapted to yield a reverse hybridisation assay on membrane-based strips with SSOs immobilised in a linewise fashion and the initially described chemiluminescence detection protocol was adapted to yield a colorimetric visualisation of positive hybridisation, using the chromogen 5-Bromo-4-chloro-3-indocylphosphate/nitroblue tetrazolium chloride 
(NBT/BCIP) substrates (Innogenetics NV, Gent).

The assay described here could not distinguish the DRB1*1501/1502, DRB1*1601/ 1602 and $\mathrm{DRB} 1^{\star} 0701 / 0702$ alleles. Those alleles were respectively grouped as DRB1*1500, DRB1*1600, and DRB1*0700.

For DRB genotyping, some allelic combinations couldn't be deducted because of overlapping sequences. Thus instead of the original coamplification, a group specific PCR was developed for DRB1 (all DRB1 alleles except DR2, DR7 and DR9 groups) and also for DR4 and DR2. The DR4 amplification is described by Buysse et al. ${ }^{25}$ In the DRB1 locus specific PCR, the previously described DRB1 primer CRX37 (5'-GAATTCCCGCGCCGCGCT $\left.-3^{\prime}\right)^{26}$ was used in combination with the conserved DRB-1 primer (5'-GATCCTTCGTGTCCCCACAGCACG-3'). ${ }^{25}$ For DR2 group-specific amplification the DR2-DRB1 primer (5'-TTCCTGTGGCAGCCTAAGAGG-3') of the 11th International Histocompatibility Workshop was combined with the conserved DRB-2 primer (5'-GCCGCTGCACTGTGAAGCTCTC-3'). The PCR conditions for the DRB1 locus as well as for the DR2 specific amplification were identical to those of the coamplification. ${ }^{25}$

STATISTICAL ANALYSIS

Allelic, genotypic and haplotypic distributions in the RA patients and control group were compared by using the Chi square and Fisher's exact test of independence. ${ }^{27}$ Data were considered significant at $p<0 \cdot 05$. Bonferoni correction for multiple testing was done. ${ }^{28}$ Additionally, the alleles were examined for a second RA association by the 'Relative Predispositional Effects' (RPE) method. ${ }^{29}$ In this method, allele frequencies are examined sequentially and according to strength; thus the problem that a strong association with one allele can create misleading deviations in the frequencies of other alleles is alleviated. Relative Risk (RR, Odds ratio) was calculated using the formula (number of patients with the specific allele/number of patients without this allele)/(number of controls with the specific

Table $2 a$ Frequency of $H L A-D R B 1{ }^{*} 04$ alleles in the study population

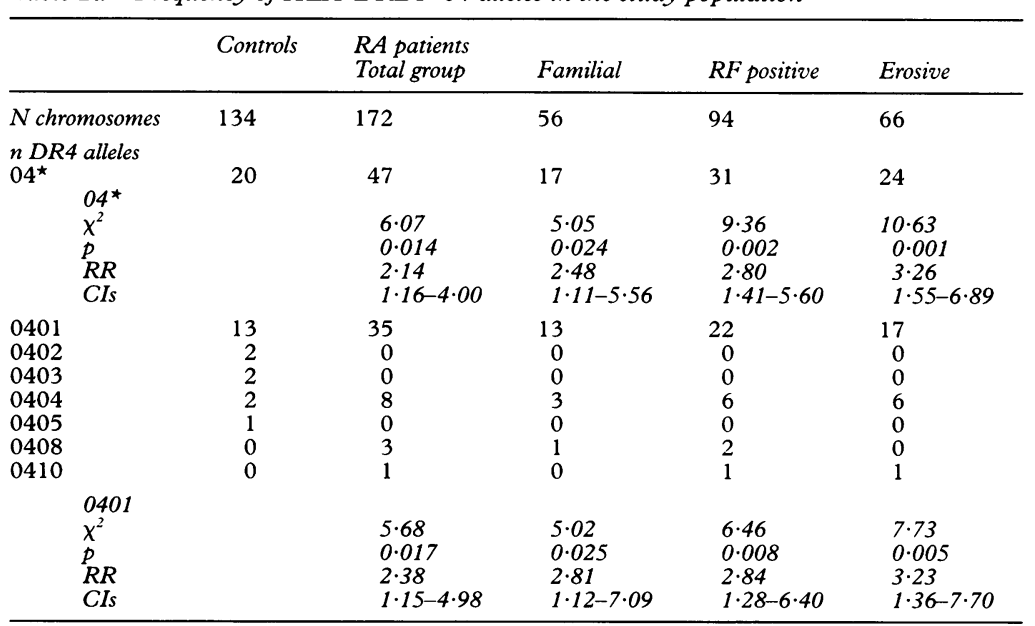

RR: relative risk; CIs. 95\% Confidence intervals allele/number of controls without this allele); 95\% Confidence limits of RR are given (95\% CIs).

Allele frequencies were defined as the number of times an allele (band) appeared and was counted once in a heterozygote and twice in a homozygote person. Genotype frequencies were defined as the number of times a particular combination of alleles (bands) appeared in either a homozygotic pattern or a heterozygotic pattern.

\section{Results}

HLA CLASS II POLYMORPHISMS

The frequencies of the $\mathrm{DRB} 1^{\star} 04$ polmorphisms are shown in table $2 \mathrm{a}$. It can be seen that the previously observed ${ }^{30}$ disease association with HLA-DR4 in White patients with RA is also present in our patient population $(\mathrm{RR}=2 \cdot 14,95 \% \mathrm{CI}=1 \cdot 16-4 \cdot 00)$. Within the DR4 positive individuals, the distribution of $\mathrm{DRB} 1{ }^{\star} 04$ alleles did not show any statistically significant difference between $\mathrm{RA}$ and controls. In the DR4 positive RA population, about $74 \%$ is associated with the allele HLA DRB $1^{\star} 0401$ (Dw4), $17 \%$ with ${ }^{\star} 0404$ (Dw 14) and 6\% with ${ }^{\star} 0408$ (Dw14). No association was found with the other $\mathrm{DRB} 1^{\star} 04$ alleles studied. Only five patients $(6 \%)$ were homozygous for the HLA-DR4 haplotype.

This disease association with HLA$\mathrm{DRB} 1{ }^{\star} 04$ was also observed in the patients with familial RA (group 1, table 1). Of 28 patients, 16 expressed at least one diseaseassociated HLA-DRB ${ }^{\star} 04$ allele $(\mathrm{RR}=2 \cdot 81$, $95 \% \mathrm{CI}=1 \cdot 12-7 \cdot 09)$. The $\mathrm{DRB}^{\star} 0401$ subtype was the most frequent variant present in this patient population, and one patient was homozygous for this disease-linked $\mathrm{DRB} 1{ }^{\star} 0401$ allele.

When subgrouping the patients according to clinical symptoms related to more severe RA, the HLA-DR4 association was more pronounced: 27 out of 48 rheumafactor positive patients (group 2, table 1$)(\mathrm{RR}=2 \cdot 80,95 \%$ $\mathrm{CI}=1 \cdot 41-5 \cdot 60)$ and 20 of 33 patients with erosive RA (group 3, table 1) $(R R=3 \cdot 26,95 \%$ $\mathrm{CI}=1 \cdot 55-6 \cdot 89)$ were DR4 positive. Also in these subsets the $\mathrm{DRB} 1^{\star} 0401$ allele was most frequently present.

The presence of a strongly predisposing allele, such as DR4 for RA, can mask the presence of a second disease association. The RPE method ${ }^{29}$ was therefore applied, but no new RA association was detected.

The previously reported RA association with DRB $1{ }^{\star} 01$ and ${ }^{\star} 06$ alleles, ${ }^{31}$ could not be detected, in spite of subgrouping our RA population. Furthermore, no significant difference in DRB3-4-5 allele distribution among the RA patients and controls was observed (table $2 b$ ).

TCRB POLYMORPHISMS

Eighty eight patients with RA (table 3, total group) and 67 healthy controls were investigated for three TCRB RFLPs, TCRBC2/Bgl II, TCRBV8/Bam HI, and TCRBV11/Bam HI 
Table $2 b \quad$ Frequencies of HLA class II DRB alleles in Belgian patients with $R A$ and controls

\begin{tabular}{|c|c|c|c|c|c|c|}
\hline$H L A$ alleles & $\begin{array}{l}\text { Patients } \\
(N=172 \\
\text { chromosomes) }\end{array}$ & & $\begin{array}{l}\text { Controls } \\
(N=134 \\
\text { chromosomes) }\end{array}$ & & $p$ value & $R R(C I s)$ \\
\hline \multicolumn{7}{|c|}{ frequencies } \\
\hline 0101 & 20 & $0 \cdot 116$ & 9 & 0.067 & & \\
\hline 0102 & 1 & 0.006 & 4 & 0.030 & & \\
\hline 0301 & 21 & 0.122 & 13 & 0.097 & & \\
\hline 0401 & 35 & 0.203 & 13 & 0.097 & & \\
\hline 0402 & 0 & 0 & 2 & 0.015 & & \\
\hline 0403 & 0 & 0 & 2 & 0.015 & & \\
\hline 0404 & 8 & 0.046 & 2 & 0.015 & & \\
\hline 0405 & 0 & 0 & 1 & 0.007 & & \\
\hline 0408 & 3 & 0.017 & 0 & 0 & & \\
\hline 0410 & 1 & 0.006 & 0 & 0 & & \\
\hline 0700 & 14 & 0.081 & 15 & $0 \cdot 111$ & & \\
\hline 0801 & 2 & 0.012 & 3 & 0.022 & & \\
\hline 0901 & 7 & 0.041 & 1 & 0.007 & & \\
\hline 1001 & 6 & 0.035 & 2 & 0.015 & & \\
\hline 1101 & 16 & 0.093 & 16 & $0 \cdot 119$ & & \\
\hline 1102 & 0 & 0 & 1 & 0.007 & & \\
\hline 1103 & 7 & 0.041 & 3 & 0.022 & & \\
\hline 1201 & 1 & 0.006 & 4 & 0.030 & & \\
\hline 1202 & 1 & 0.006 & 0 & 0 & & \\
\hline 1300 & 14 & 0.081 & 22 & $0 \cdot 164$ & & \\
\hline 1401 & 6 & 0.035 & 6 & 0.045 & & \\
\hline 1500 & 8 & 0.047 & 11 & 0.082 & & \\
\hline 1600 & 1 & 0.006 & 4 & 0.030 & & \\
\hline 0400 & 47 & $0 \cdot 273$ & 20 & $0 \cdot 149$ & 0.014 & $2 \cdot 14(1 \cdot 16-4 \cdot 0)$ \\
\hline \multicolumn{7}{|l|}{$D R B 3$} \\
\hline 0101 & 19 & $0 \cdot 110$ & 19 & $0 \cdot 142$ & & \\
\hline 0200 & 34 & $0 \cdot 198$ & 37 & 0.276 & & \\
\hline 0202 & 3 & 0.017 & 0 & 0 & & \\
\hline 0301 & 9 & 0.052 & 9 & $0 \cdot 067$ & & \\
\hline no DRB3 & 107 & 0.622 & 69 & 0.515 & & \\
\hline \multicolumn{7}{|l|}{$D R B 4$} \\
\hline 0101 & 69 & 0.401 & 36 & $0 \cdot 269$ & & \\
\hline no DRB4 & 103 & 0.599 & 98 & 0.731 & & \\
\hline \multicolumn{7}{|l|}{ DRB5 } \\
\hline 0101 & 9 & 0.052 & 11 & 0.082 & & \\
\hline 0200 & 1 & 0.006 & 3 & 0.030 & & \\
\hline no DRB5 & 162 & 0.942 & 119 & 0.888 & & \\
\hline
\end{tabular}

$\mathrm{DRB} 1{ }^{\star} 0400$ group contains all DRB $1^{\star} 04$ alleles.

DRB1* 1300 group contains DRB1* $1301 / 1302 / 1303 / 1305$ alleles.

DRB $1 \star 1501 / 1502$. DRB $1^{\star} 0701 / 0702$ and DRB1*1601/1602 were grouped at DRB1 1500 DRB $1{ }^{\star} 0700$ and $\mathrm{DRB} 1{ }^{\star} 1600$ respectively.

$R R$, relative risk; CIs $95 \%$ confidence intervals.

(figure). These three TCRB RFLPs did not exhibit significant differences in allele or genotype frequencies between RA patients and controls. No extra bands or aberrant restriction fragment sizes were identified among the RA patients, indicating that no major TCRB gene deletions or duplications could be found in these patients.

Although these TCRB RFLPs are associated with only two alleles, their combination results in haplotypes with a limited linkage disequilibrium between the various markers in the TCRBV and TCRBC regions. ${ }^{32}$ Analysis of the haplotypes assembled from our data also failed to reveal differences between RA patients (Total group, table 1) and controls (table 4).

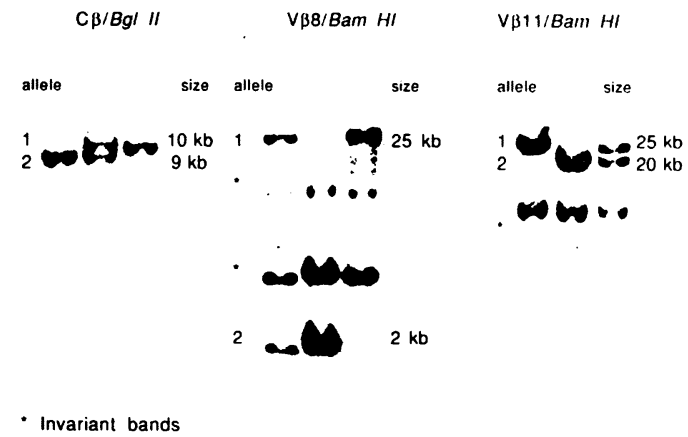

$T$-cell receptor $\beta$ chain polymorphisms. The hybridisation pattern at each locus is displayed by Southern blots for both homozygotes and heterozygotes.

Table 4 The distribution of the TCRBV8/Bam HITCRBV11/Bam HI-TCRBC2/Bgl II haplotypes in RA and control group

\begin{tabular}{lrrll}
\hline $\begin{array}{l}\text { TCRB-V8-V11-C2 } \\
\text { haplotype }\end{array}$ & Observed & \multicolumn{3}{l}{ Frequencies } \\
\hline & \multicolumn{5}{l}{ Control } & $R A$ & Control \\
A: $23 / 25 / 10^{\star 2}$ & 2 & 3 & $0 \cdot 02$ & $0 \cdot 04$ \\
B: $2 / 25 / 10$ & 27 & 17 & $0 \cdot 25$ & $0 \cdot 24$ \\
C: $23 / 20 / 10$ & 19 & 12 & $0 \cdot 18$ & $0 \cdot 17$ \\
D: $2 / 20 / 10^{\star}$ & 6 & 4 & $0 \cdot 06$ & $0 \cdot 06$ \\
E: $23 / 25 / 9^{\star}$ & 1 & 3 & $0 \cdot 01$ & $0 \cdot 04$ \\
F: $2 / 25 / 9$ & 14 & 11 & $0 \cdot 13$ & $0 \cdot 16$ \\
G: $23 / 20 / 9$ & 35 & 17 & $0 \cdot 32$ & $0 \cdot 24$ \\
H: $2 / 20 / 9^{\star}$ & 4 & 3 & $0 \cdot 04$ & $0 \cdot 04$ \\
Total number of & 108 & 70 & & \\
haplotypes & & & & \\
\hline
\end{tabular}

$\chi^{2}=4 \cdot 269, \mathrm{p}>0.5(7 \mathrm{df})$

$\chi^{2}=2.443, p>0.5(4 \mathrm{df}$

Data for the 4 lowest $\left({ }^{\star}\right)$ frequencies were combined before Chi-square analysis.

We also analysed these TCRB RFLPs in the RA patient subsets (table 1), neither the allele nor the genotype frequencies for the different groups of patients were significantly different from the control data (table 3 ).

HLA-DR4 POSITIVE INDIVIDUALS

Forty two of $87(48 \%)$ of the Belgian patients with RA used in this study were DR4 positive, compared with 18 of $37(27 \%)$ of the control individuals. To determine if HLA contributes to differences in TCRB allele or genotype frequencies, we analysed TCRB RFLPs for both RA patients and controls positive for DR4 (table 5). We observed an increase in frequency of the $23 \mathrm{~kb}$ TCRBV8 allele in the RA populations $(0.51$ vs. 0.32$)$ which, however,

Table 3 Human TCRB RFLP allele and genotype frequencies in Belgian patients with $R A$ and controls

\begin{tabular}{|c|c|c|c|c|c|c|c|c|c|c|c|}
\hline \multicolumn{12}{|c|}{ Rheumatoid arthritis patients } \\
\hline $\begin{array}{l}\text { Probe/enzyme } \\
\text { TCRBC2/Bgl II }\end{array}$ & $\begin{array}{l}\begin{array}{c}\text { Allele } \\
(\mathrm{kb})\end{array} \\
1(9) \\
2(10)\end{array}$ & $\begin{array}{l}\text { Controls } \\
\text { Obs. } \\
72 \\
62\end{array}$ & $\begin{array}{l}\text { Freq. } \\
0.54 \\
0.46\end{array}$ & $\begin{array}{l}\text { Total group } \\
\text { Obs. } \\
91 \\
85\end{array}$ & $\begin{array}{l}\text { Freq. } \\
0.55 \\
0.48\end{array}$ & $\begin{array}{l}\text { Familial } \\
\text { Obs. } \\
35 \\
21\end{array}$ & $\begin{array}{l}\text { Freq. } \\
0.62 \\
0 \cdot 38\end{array}$ & $\begin{array}{l}R F \text { positive } \\
\text { Obs. } \\
42 \\
54\end{array}$ & $\begin{array}{l}\text { Freq. } \\
0.44 \\
0.56\end{array}$ & $\begin{array}{l}\text { Erosive } \\
\text { Obs. } \\
37 \\
29\end{array}$ & $\begin{array}{l}\text { Freq. } \\
0 \cdot 56 \\
0 \cdot 44\end{array}$ \\
\hline TCRBV8/Bam HI & $\begin{array}{l}1(2) \\
2(23)\end{array}$ & $\begin{array}{l}74 \\
60\end{array}$ & $\begin{array}{l}0.55 \\
0.45\end{array}$ & $\begin{array}{l}85 \\
91\end{array}$ & $\begin{array}{l}0.48 \\
0.52\end{array}$ & $\begin{array}{l}28 \\
28\end{array}$ & $\begin{array}{l}0.50 \\
0.50\end{array}$ & $\begin{array}{l}46 \\
50\end{array}$ & $\begin{array}{l}0.48 \\
0.52\end{array}$ & $\begin{array}{l}31 \\
35\end{array}$ & $\begin{array}{l}0.47 \\
0.53\end{array}$ \\
\hline TCRBV11/Bam HI & $\begin{array}{l}1(20) \\
2(25)\end{array}$ & $\begin{array}{l}71 \\
63\end{array}$ & $\begin{array}{l}0.53 \\
0.47\end{array}$ & $\begin{array}{l}98 \\
78\end{array}$ & $\begin{array}{l}0 \cdot 56 \\
0 \cdot 44\end{array}$ & $\begin{array}{l}32 \\
24\end{array}$ & $\begin{array}{l}0.57 \\
0.43\end{array}$ & $\begin{array}{l}54 \\
42\end{array}$ & $\begin{array}{l}0.56 \\
0 \cdot 44\end{array}$ & $\begin{array}{l}40 \\
36\end{array}$ & $\begin{array}{l}0 \cdot 61 \\
0 \cdot 39\end{array}$ \\
\hline TCRBC2/Bgl II & $\begin{array}{c}\text { Genotype } \\
9,9 \\
9,10 \\
10,10\end{array}$ & $\begin{array}{l}21 \\
30 \\
16\end{array}$ & $\begin{array}{l}0.31 \\
0.45 \\
0 \cdot 24\end{array}$ & $\begin{array}{l}28 \\
35 \\
25\end{array}$ & $\begin{array}{l}0 \cdot 32 \\
0 \cdot 42 \\
0 \cdot 28\end{array}$ & $\begin{array}{r}11 \\
13 \\
4\end{array}$ & $\begin{array}{l}0 \cdot 39 \\
0 \cdot 46 \\
0 \cdot 14\end{array}$ & $\begin{array}{l}10 \\
22 \\
16\end{array}$ & $\begin{array}{l}0.21 \\
0.46 \\
0.33\end{array}$ & $\begin{array}{r}10 \\
17 \\
6\end{array}$ & $\begin{array}{l}0 \cdot 30 \\
0 \cdot 52 \\
0 \cdot 20\end{array}$ \\
\hline TCRBV8/Bam HI & $\begin{array}{c}2,2 \\
2,23 \\
23,23\end{array}$ & $\begin{array}{l}21 \\
32 \\
14\end{array}$ & $\begin{array}{l}0 \cdot 31 \\
0 \cdot 48 \\
0 \cdot 21\end{array}$ & $\begin{array}{l}26 \\
33 \\
29\end{array}$ & $\begin{array}{l}0 \cdot 30 \\
0 \cdot 38 \\
0 \cdot 33\end{array}$ & $\begin{array}{r}10 \\
8 \\
10\end{array}$ & $\begin{array}{l}0 \cdot 36 \\
0 \cdot 29 \\
0 \cdot 36\end{array}$ & $\begin{array}{l}13 \\
20 \\
15\end{array}$ & $\begin{array}{l}0 \cdot 28 \\
0 \cdot 42 \\
0 \cdot 31\end{array}$ & $\begin{array}{r}9 \\
13 \\
11\end{array}$ & $\begin{array}{l}0 \cdot 27 \\
0 \cdot 39 \\
0 \cdot 33\end{array}$ \\
\hline TCRBV11/Bam HI & $\begin{array}{l}20,20 \\
20,25 \\
25,25\end{array}$ & $\begin{array}{l}21 \\
29 \\
17\end{array}$ & $\begin{array}{l}0 \cdot 31 \\
0 \cdot 43 \\
0 \cdot 25\end{array}$ & $\begin{array}{l}32 \\
34 \\
22\end{array}$ & $\begin{array}{l}0.36 \\
0 \cdot 39 \\
0 \cdot 25\end{array}$ & $\begin{array}{r}12 \\
8 \\
8\end{array}$ & $\begin{array}{l}0.43 \\
0 \cdot 29 \\
0 \cdot 29\end{array}$ & $\begin{array}{l}18 \\
18 \\
12\end{array}$ & $\begin{array}{l}0 \cdot 38 \\
0 \cdot 38 \\
0 \cdot 25\end{array}$ & $\begin{array}{r}15 \\
10 \\
8\end{array}$ & $\begin{array}{l}0.45 \\
0.30 \\
0 \cdot 24\end{array}$ \\
\hline
\end{tabular}


Table 5 Human TCRB RFLP allele and genotype frequencies in Belgian DR4 positive RA patients and controls

\begin{tabular}{|c|c|c|c|c|c|c|c|c|c|c|c|}
\hline \multicolumn{12}{|c|}{ Rheumatoid arthritis patients } \\
\hline $\begin{array}{l}\text { Probe/enzyme } \\
\text { TCRBC2/Bgl II }\end{array}$ & $\begin{array}{l}\text { Allele } \\
(\mathrm{kb}) \\
1(9) \\
2(10)\end{array}$ & $\begin{array}{l}\text { Controls } \\
\text { Obs. } \\
18 \\
14\end{array}$ & $\begin{array}{l}\text { Freq. } \\
0.56 \\
0.44\end{array}$ & $\begin{array}{l}\text { Total group } \\
\text { Obs. } \\
44 \\
40\end{array}$ & $\begin{array}{l}\text { Freq. } \\
0 \cdot 52 \\
0 \cdot 48\end{array}$ & $\begin{array}{l}\text { Familial } \\
\text { Obs. } \\
21 \\
11\end{array}$ & $\begin{array}{l}\text { Freq. } \\
0.66 \\
0.34\end{array}$ & $\begin{array}{l}R F \text { positive } \\
\text { Obs. } \\
24 \\
30\end{array}$ & $\begin{array}{l}\text { Freq. } \\
0.44 \\
0.56\end{array}$ & $\begin{array}{l}\text { Erosive } \\
\text { Obs. } \\
23 \\
19\end{array}$ & $\begin{array}{l}\text { Freq. } \\
0.55 \\
0.45\end{array}$ \\
\hline TCRBV8/Bam HI & $\begin{array}{l}1(2) \\
2(23)\end{array}$ & $\begin{array}{l}23 \\
11\end{array}$ & $\begin{array}{l}0.68 \\
0.32\end{array}$ & $\begin{array}{l}41 \\
43\end{array}$ & $\begin{array}{l}0.49 \\
0.51\end{array}$ & $\begin{array}{l}16 \\
16\end{array}$ & $\begin{array}{l}0.50 \\
0.50\end{array}$ & $\begin{array}{l}27 \\
27\end{array}$ & $\begin{array}{l}0.50 \\
0.50\end{array}$ & $\begin{array}{l}23 \\
19\end{array}$ & $\begin{array}{l}0.55 \\
0.45\end{array}$ \\
\hline TCRBV11/Bam $\mathrm{HI}$ & $\begin{array}{l}1(20) \\
2(25)\end{array}$ & $\begin{array}{l}15 \\
17\end{array}$ & $\begin{array}{l}0.47 \\
0.53\end{array}$ & $\begin{array}{l}48 \\
36\end{array}$ & $\begin{array}{l}0.57 \\
0.43\end{array}$ & $\begin{array}{l}20 \\
12\end{array}$ & $\begin{array}{l}0.63 \\
0 \cdot 38\end{array}$ & $\begin{array}{l}30 \\
24\end{array}$ & $\begin{array}{l}0.56 \\
0.44\end{array}$ & $\begin{array}{l}23 \\
19\end{array}$ & $\begin{array}{l}0.55 \\
0.45\end{array}$ \\
\hline TCRBC2/Bgl II & $\begin{array}{c}\text { Genotype } \\
9,9 \\
9,10 \\
10,10\end{array}$ & $\begin{array}{l}6 \\
6 \\
4\end{array}$ & $\begin{array}{l}0.38 \\
0.38 \\
0 \cdot 25\end{array}$ & $\begin{array}{l}13 \\
18 \\
11\end{array}$ & $\begin{array}{l}0 \cdot 31 \\
0 \cdot 43 \\
0 \cdot 26\end{array}$ & $\begin{array}{l}7 \\
7 \\
2\end{array}$ & $\begin{array}{l}0 \cdot 44 \\
0 \cdot 44 \\
0 \cdot 13\end{array}$ & $\begin{array}{r}6 \\
12 \\
9\end{array}$ & $\begin{array}{l}0 \cdot 22 \\
0 \cdot 44 \\
0 \cdot 33\end{array}$ & $\begin{array}{r}6 \\
11 \\
4\end{array}$ & $\begin{array}{l}0 \cdot 29 \\
0 \cdot 52 \\
0 \cdot 19\end{array}$ \\
\hline TCRBV8/Bam HI & $\begin{array}{l}2,2 \\
2,23 \\
23,23\end{array}$ & $\begin{array}{l}7 \\
9 \\
1\end{array}$ & $\begin{array}{l}0.41 \\
0.53 \\
0.06\end{array}$ & $\begin{array}{l}13 \\
15 \\
14\end{array}$ & $\begin{array}{l}0 \cdot 31 \\
0 \cdot 36 \\
0 \cdot 33\end{array}$ & $\begin{array}{l}6 \\
4 \\
6\end{array}$ & $\begin{array}{l}0 \cdot 38 \\
0 \cdot 25 \\
0 \cdot 38\end{array}$ & $\begin{array}{r}8 \\
11 \\
8\end{array}$ & $\begin{array}{l}0 \cdot 30 \\
0 \cdot 41 \\
0 \cdot 30\end{array}$ & $\begin{array}{l}7 \\
9 \\
5\end{array}$ & $\begin{array}{l}0.33 \\
0 \cdot 43 \\
0 \cdot 16\end{array}$ \\
\hline TCRBV11/Bam $\mathrm{HI}$ & $\begin{array}{l}20,20 \\
20,25 \\
25,25\end{array}$ & $\begin{array}{l}4 \\
7 \\
5\end{array}$ & $\begin{array}{l}0.25 \\
0 \cdot 44 \\
0 \cdot 31\end{array}$ & $\begin{array}{l}17 \\
14 \\
11\end{array}$ & $\begin{array}{l}0.40 \\
0.33 \\
0.26\end{array}$ & $\begin{array}{l}8 \\
4 \\
4\end{array}$ & $\begin{array}{l}0.50 \\
0 \cdot 25 \\
0 \cdot 25\end{array}$ & $\begin{array}{r}11 \\
8 \\
8\end{array}$ & $\begin{array}{l}0 \cdot 41 \\
0 \cdot 30 \\
0 \cdot 30\end{array}$ & $\begin{array}{l}8 \\
7 \\
6\end{array}$ & $\begin{array}{l}0 \cdot 38 \\
0 \cdot 33 \\
0 \cdot 29\end{array}$ \\
\hline
\end{tabular}

was not statistically significant. When analysing the TCRBV8 genotypes, a trend towards a predominant expression of the homozygous $23 \mathrm{~kb}$ genotype was observed in the total RA population (Total group, $p=0.0291$ ), and in the RA patients with familial RA (group 1, $p=0.0270$ ).

When the haplotype frequencies, defined the two TCRBV probes and one TCRB probe in the DR4 positive subset of RA patients, were compared with the distribution in the DR4 positive control group, no significant difference was found (data not shown).

\section{Discussion}

As RA is assumed to be an immunopathological disease, developing in a genetic susceptible host, the search for genomic regions predisposing to $\mathrm{RA}$ has focused on genes coding for components of the immune system.

So far the role of the MHC has been most extensively studied, because of the central position of the MHC gene products in the antigen presentation. In this study, as well as in previous studies of patients of northern European White ancestry with $\mathrm{RA}^{7-9}$ a prominent association with the HLA-DR4 haplotype ( $48 \%$ of RA patients $v 27 \%$ of controls) was detected. Furthermore, the Belgian patients with RA appeared to be genetically very homogeneous, $74 \%$ of the DR4 positive patients express the allele $\mathrm{DRB}^{\star} 0401$ (Dw4) and $23 \%$ DRB $1^{\star} 0404 /{ }^{\star} 0408$ (Dw14). No association was found with the other ${ }^{\star} 04$ alleles studied. These results are in good agreement with previous observations. ${ }^{33}$

These disease-associated HLA-DRB $1{ }^{\star} 04$ alleles (Dw4, Dw14) share a common sequence (amino acid positions 70-74 of the HVR3), which is not present in the HLADw10 and HLA-Dw13 subtypes. ${ }^{34}$ Thus as this sequence QKRAA (Dw4)/QRRAA (Dw14/DR1) is expressed in the HVR3 of the DR $\beta 1$ chain in most RA patients, it has been proposed that this sequence motif is responsible for the disease susceptibility. This phenomenon is known as the 'shared epitope hypothesis' ${ }^{35}$ It has been postulated that, as peptides from the same area of MHC class II- molecules are able to modulate the T-cell repertoire by deleting self-reactive $T$ cells, $R A$ may originate from a particular $T$-cell repertoire, imposed by the sequence QRKAA/ QRRAA. ${ }^{35} 36$

We subsequently analysed the allelic combination of HLA-DRB $1^{\star} 0401$ and ${ }^{\star} 0404$ alleles in individual patients and controls, to address the question whether the second haplotype influences the presentation of the disease. Only five patients $(6 \%)$ were homozygous for the HLA-DR4 haplotype. This is much lower than observed by Weyand et al, ${ }^{14}$ $27 \%$ of their RA patients were homozygous for HLA-DR4.

To correlate the HLA-DR4 haplotype with the inheritance and clinical manifestation of the disease, we defined three groups of RA patients. Familial RA was highly associated with the HLA-DRB $1^{\star} 04$ alleles. $57 \%$ of these patients ( 16 of 28 ) expressed at least one of the disease-associated alleles. Also in the two patient subsets representing the more severe forms of RA, a clear association with the molecular polymorphisms of the HLA$\mathrm{DRB} 1^{\star} 04$ gene was observed. The high frequency of the HLA-DR4 genotype in these two disease categories, strongly supports the association of RA with this haplotype. The strong association in these patient subgroups (RR of 2.80 in group 2 and $R R$ of 3.46 in group $3 v \mathrm{RR}$ of $2 \cdot 14$ in the total RA patient population), is most likely due to the patient selection, and suggests that RA patients with severe disease show a more pronounced association with the HLA-DRB $1^{\star} 0401$ and $\star 404$ alleles, as has been suggested by others. ${ }^{14} 1537$ Severe RA therefore seems to be immunogenetically different from the milder forms of the disease.

We could not confirm the disease association with the DRB1*0101 allele as has been

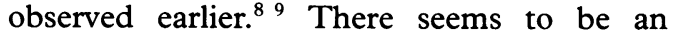
increase in the frequency of this allele among our RA patients, but this increase is not statistically significant. This was also the case in the different patient subsets. Furthermore, no significant difference in the HLA-DRB34-5 allele distribution among the RA patients and controls was observed, suggesting that the RA-associated HLA-genotype do not extend to 
these regions.

Because the inheritance of predisposing HLA-alleles cannot account for all of the genetic susceptibility to RA, and since T-lymphocytes play a central role in immune recognition through the antigen specific TCRA and TCRB chains, a number of investigators have tested the hypothesis that genetic variations in the TCRA and TCRB germline genes may play a role in the susceptibility to autoimmune diseases. ${ }^{38}{ }^{39}$ The identification of a critical TCR in autoimmune diseases could provide a specific site for clinical intervention. ${ }^{40}$

In 1988 Gao et $a l^{16}{ }^{17}$ reported an association between the DR4 haplotype and the $2 \mathrm{~kb}$ TCRBV8 allele from a Bam HI digest. These results were confirmed by some investigators, ${ }^{18}$ but could not be confirmed by others, in spite of various ways of subgrouping patients according to the HLA-phenotype and clinical symptoms. ${ }^{19} 2041$

In summary, contradictory data have been reported by different groups, and a clear cut disease association with RFLP-defined alleles of the TCR genes is not evident. Furthermore, until now there has been no evidence that these germline genes actually play a functional role in the pathogenesis of RA or other autoimmune diseases.

A well-characterised RA patient population was studied, using established molecular genetic techniques, to evaluate TCRB chain RFLPs. We could not identify any significant difference in allele or genotype frequencies between RA patients and controls for the three TCR-RFLPs studied, and this in spite of subgrouping our RA population according to clinical symptoms. Despite the fact that only two alleles are associated with these TCRRFLPs, their combination results in haplotypes in a limited linkage disequilibrium with the various markers in the TCRBV and TCRBC regions. ${ }^{42}$ However, the distribution of the haplotypes defined by TCRBV8, TCRBV11 and TCRBC2 RFLP alleles in our group of RA patients was not different from that found in the control group.

In the RA population studied, 42 of 87 $(48 \%)$ patients were DR4 positive, compared with 18 of $67(27 \%)$ control persons. Analysis of only this DR4 positive subgroup showed an increase in frequency of the $23 \mathrm{~kb}$ TCRBV8 allele: $51 \%$ compared with $32 \%$ in the DR4 positive control population, in whom the $2 \mathrm{~kb}$ TCRBV8 allele was more frequently used. This difference, however, was not statistically significant. When analysing the TCRBV8 genotypes, a trend towards an over-representation of the homozygous $23 \mathrm{~kb}$ genotype in the total DR4+ RA population $(p=0.0291)$, and in the RA patients with familial RA $(p=0.0270)$ was observed. These data are at variance with the findings of Funkhouser et $a l,{ }^{18}$ who found a significant difference in the TCRBV8/Bam HI allele frequency between this RA population and controls; in their hands the $2 \mathrm{~kb}$ fragment occurred with much greater frequency than the $23 \mathrm{~kb}$ fragment in the DR4 positive RA patients $(n=26)$. This over- representation was reflected in a predominance of the homozygous $2 \mathrm{~kb}$ genotype. We failed to confirm these findings, in spite of subgrouping our DR4+ RA patients according to clinical symptoms. The conflicting results obtained in our study and those who reported positive associations with TCRB polymorphisms can be explained by, first, disease heterogeneity, leading to contamination in the population study and second, by statistical errors due to insufficient correction for multiple comparisons, and also by genetic differences between the RA populations studied.

In conclusion, we have been able to confirm the known association of RA with the HLA$\mathrm{DRB}^{\star} 04$ genotype in the Belgian RA population. This association was also present in familial RA, and was even more pronounced in patients with more severe RA. We could not show any statistical significant association of RA with RFLP-defined allelic patterns of the TCRB chain genes, in spite of various ways of subgrouping patients according to clinical symptoms and HLA-genotype. Furthermore, a combined presence of different polymorphic markers, such as DR4, TCRBC, TCRBV8 and TCRBV11, is not essential for increasing the susceptibility to RA. This study indicates that there is no evidence for an association of clinically definite RA with RFLPs of the TCRB chain in patients of White ancestry.

This work was supported by the Sociale Investeringsmaatschappij Limburg (SIM), the Nationaal Fonds voo Wetenschappeliik Onderzoek (NFWO), and the InterUniversitaire Attractie Polen (IUAP)

We thank Dr M-P Jacobs, Dr J Zhang and Dr P Stinissen for helpful discussions, and Professor $\mathrm{H}$ Callaert for statistical evaluation.

1 Krane S M, Simon L S. Rheumatoid arthritis: clinical features and pathogenetic mechanisms. Med Clin North Am 1986; 70: 263-84

2 Panayi G S, Lanchbury J S, Kingsley G H. The importance of the $T$ cell in initiating and maintaining the chronic of the $T$ cell in iniating and maintis (editorial) Arthritis Rheum 1992; 35: 729-35.

3 Nunez G, Moore S, Ball G V, Hurd E R, Stastny P. Study of HLA antigens in ten multiple-case rheumatoid arthritis families. $\mathcal{F}$ Rheumatol 1984; 11: 129-35.

4 Rigby A S. HLA haplotype sharing in Rheumatoid Arthritis sibships: risk estimates in siblings. Scand $\mathcal{F}$ Rheumato 1992; 21: 68-73.

5 Silman A J, MacGregor A J, Thomson W, et al. Twin concordance rates for rheumatoid arthritis: results from a nationwide study. Brf Rheumatol 1993; 32: 903-7.

6 Jarvinen P, Koskenvuo M, Koskimies S, Kotaniemi K, Aho $K$. Rheumatoid arthritis in identical twins: a clinical and immunogenetic study of eight concordant pairs derived from a nationwide twin panel. Scand 7 Rheumatol 1991 20: $159-64$.

7 Stastny P. Mixed lymphocyte cultures in patients with theumatoid arthritis. 7 Clin Invest 1976; 5: 1148-64.

8 Woodrow J C, Nichol F E, Zaphiropoulos G. DR antigens and rheumatoid arthritis: a study of two populations. $B M \mathcal{A}$ 1981; 283: 1287-8.

9 Schiff B, Mizzachi Y, Orgad S, Yaron M, Gazit E. Association of HLA-Aw31 and HLA-DR1 with adul rheumatoid arthritis. Ann Rheum Dis 1982; 41: 403-4.

10 Singal D M, Reid B, Kassam Y B, D'Souza M, Bensen W G, Adachi J G. HLA-DQ beta-chain polymorphism in HLA- DR4 haplotypes associated with rheumatoid arthritis. Lancet 1987; II: 118-20.

11 Wallin J, Carlsson B, Ström H, Möller E. A DR4-associated DR-DQ haplotype is significantly associated with rheumatoid arthritis. Arthritis Rheum 1988; 31: 72-9.

12 Willkens R F, Nepom G T, Marks C R, Nettles J W, Nepom B S. Association of HLA-Dw 16 with rheumatoid arthritis in Yakima Indians: further evidence for the 'shared in Yakima Indians: further evidence for the 's

13 Angelini G, Morozzi G, Delfino L, et al. Analysis of HLA DP, DQ and DR alleles in adult Italian rheumatoid DP, DQ and DR alleles in adult Italian rheu

14 Weyand C, Hicok K C, Conn D L, Goronzy J J. The influence of HLA-DRB 1 genes on disease severity in Rheumatoid Arthritis. Ann of Int Med 1992, 117. 801-6.

15 Thomson W, Pepper L, Payton A, et al. Absence of an association between HLA-DRB ${ }^{\star} 04$ and rheumatoid 
arthritis in newly diagnosed cases from the community. Ann Rheum Dis 1993; 52: 539-41.

16 Gao X, Ball E, Dombrausky S, et al. Class II human leukocyte antigen genes and $\mathrm{T}$ cell receptor polymorphisms in patients with rheumatoid arthritis. $A m$ f Med 1988; 85 (suppl 6A): 14-6.

17 Stastny P, Ball E J, Khan M A, Olsen N J, Pincus T, Gao $\mathrm{X}$. HLA-DR4 and other genetic markers in rheumatoid arthritis. Br $\mathcal{F}$ Rheumatol 1988; 27 (suppl II): 132-48.

18 Funkhouser S W, Concannon P, Charmley P, Vredevoe D $L$, Hood L. Differences in $T$ cell receptor restriction fragment length polymorphisms in patients with

9 Neun B S, Mathritis. Arthritis Rheum 1992, 35: 465-71. J G, Concannon P. HLA and T cell receptor polymorphisms in pauciarticular-onset juvenile rheumatoid arthritis. Arthritis Rheum 1991; 34: 1260-66.

20 Wallin J, Hillert J, Olerup O, Carlsson B, Ström H. Association of rheumatoid arthritis with a dominant DR1/ Dw4/Dw14 sequence motif, but not with T cell receptor $\beta$ chain gene alleles or haplotypes. Arthritis Rheum 1991; 34: $1416-24$.

21 Arnett F C, Edworthy S M, Bloch D A, et al. The American Rheumatism Association 1987 revised criteria for the classification of rheumatoid arthritis. Arthritis Rheum 1988; 31: 315-24.

22 Yanagi Y, Yoshikai Y, Leggett K, Clark S P, Aleksander I, Mak T W. A human T cell-specific cDNA clone encodes a protein having extensive homology to immunoglobulin chains. Nature 1984; 308: 145-9.

23 Concannon P, Pickering L A, Kung P, Hood L. Diversity and structure of human $T$-cell receptor beta-chain and structure of human T-cell receptor beta-chain variable regio

24 Sambrook J, Fritsch E F, Maniatis T, eds. Molecular cloning: a laboratory manual. 1982, New York: Cold Spring Harbor Laboratory Press, 1982: 104-7.

25 Buyse I, Decorte R, Baens M, et al. Rapid DNA typing of class II HLA antigens using the polymerase chain reaction and reverse dot blot hybridization. Tissue Antigen 1993a 41: $1-14$.

26 Scharf S J, Griffith R L, Erlich AH. Rapid typing of DNA sequence polymorphism at the HLA-DRB1 locus using the polymerase chain reaction and nonradioactive oligonucleotide probes. Hum Immunol 1991; 30: 190-201.

27 Armitage P. Statistical inference. Statistical methods in medical research. London: Blackwell Scientific Publications, 99-146, 1980.

28 Dunn O J. Estimation of the means of dependent variables. Ann Math Stat 1958; 29: 1095-111.
29 Payami H, Joe S, Farid N R, et al. Relative predispositional effects (RPEs) of marker alleles with disease: HLA-DR effects (RPEs) of marker alleles with disease: HLA-DR alleles and

30 Tiwari J, Terosaki P. HLA and disease associations. Springer Verlag: New York, 1985.

31 Wordsworth B P, Stedeford J, Rosenberg W M C, Bell J I. Limited heterogeneity of the HLA class ii contribution to susceptibility to rheumatoid arthritis is suggested by positive associations with HLA DR4, DR1 and DRw10. BrF Rheumatol 1991; 30: 178-80.

32 Charmley P, Chao A, Concannon P, Hood L, Gatti R A. Haplotyping the human T-cell receptor $\beta$-chain gene complex by use of restriction fragment length polymorphisms. Proc Natl Acad Sci USA 1990; 87: 4823-5.

33 Zoschke D, Segall M. Dw subtypes of DR4 in rheumatoid arthritis: evidence for a preferential association with Dw4. Hum Immunol 1986; 15: 118-24.

34 Weynand C M, Goronzy J J. Seropositive arthritis is associated with T-cell epitopes encoded within the third hypervariable region of the HLA-DR1 and the HLA-DR4 haplotype. Immunology of $H L A$, immuogenetics and histocompatibility $v$ II. In: Dupont $\mathrm{B}$, ed. New York: Springer-Verlag, 1989: 422-25.

35 Albani S, Roudier J. Molecular basis for the association between HLA DR4 and Rheumatoid Arthritis. From the shared epitope hypothesis to a peptide model of Rheumatoid Arthritis. Clin Biochem 1992; 25: 209-12.

36 Braun W E. HLA molecules in autoimmune diseases. Clin Biochem 1992; 25: 187-91.

37 Deighton C M. What is the future for the genetics of rheumatoid arthritis? Br f Rheumatol 1993; 32:857-61.

38 Garchon H J, Bach J F. The contributin of non-MHC genes to susceptibility to autoimmune diseases. Hum Immunol 1991; 32: $1-30$

39 Niven M J, Caffrey C, Moore R $\mathrm{H}$, et al. T-cell receptor $\beta$-subunit gene polymorphism and autoimmune disease. Hum Immunol 1990; 27: 360-7.

40 Brostoff $S$ W, Howell $M$ D. T cell receptors: immunoregulation and autoimmunity. Clin Immunol Immunopathol 1992; 62: 1-7.

41 De Vries N, Prinsen C F M, Mensink E B J M, Van Riel P L C M, Van 't Hof M A, Van de Putte L B A. A T cell receptor $\beta$ chain variable region polymorphism associated with radiographic progression in rheumatoid arthritis. Ann Rheum Dis 1993; 52: 327-31.

42 Charmley P Beall S S, Concannon P Hood L, Gatti R A. Further localization of a multiple sclerosis susceptibility gene on chromosome $7 \mathrm{q}$ using a new $\mathrm{T}$ cell receptor betachain DNA polymorphism. F Neuroimmunol 1991; 32(2):
$231-40$. 